\title{
The role of teachers in the prevention of violence of education centres
}

\author{
Maria Jesús Comellas* \\ Universitat Autònoma de Barcelona \\ (Received December 16, 2009; Accepted February 24, 2010)
}

\begin{abstract}
The observatory of violence in schools (OVE) bases its work on the consideration that the responsibility for analysing, interpreting and deciding upon educational activities to prevent violence in schools is that of all society but that it is teachers that have the ideal context for implementing systematic intervention as part of the professional commitment they have to the educational institution. This action requires teamwork in order to benefit a change of view that can shift the focus away from interpretations related to individual problems in order to analyse the relational dynamics of the group and modify them to benefit pupils as a whole (Comellas \& Lojo 2008). This research study focuses its analysis on group relationships on the basis of the demands and perceptions of the pupils themselves in order to promote the participation of teachers in working to improve group cohesion. The difficulties and opportunities are analysed along with factors of relational vulnerability in order to generate the conditions in which all of the pupils can feel that they belong to the group and the school institution. The study also includes an evaluation by teachers of the methodology used and the opportunities for improving their teaching work in relation to the class group and the prevention of school violence through the leaning about coexistence that is so implicit in the processes being proposed, and that are more closely related to the everyday life of the school institution than to a specific programme.
\end{abstract}

Key words: prevention of violence, teacher participation, group, sociogram, relational vulnerability, group belonging.

El papel del profesorado en la prevención de la violencia en los centros educativos RESUMEN: El observatorio de la violencia en las escuelas (OVE) parte de la consideración de que la responsabilidad de analizar, interpretar y decidir acciones educativas para prevenir la violencia en las escuelas recae en toda la sociedad pero es el profesorado quien dispone de un contexto óptimo para llevar a cabo una intervención sistemática desde el compromiso profesional que ha adquirido con la institución educativa. Esta acción requiere un trabajo en equipo a fin de favorecer un cambio de mirada que permita desfocalizar las interpretaciones en clave de problema individual del alumnado para analizar las dinámicas relacionales del grupo para modificarlas en beneficio de todo el alumnado (Comellas y Lojo 2008). La presente investigación focaliza el análisis en las relaciones grupales a partir de las demandas y de la percepción del propio alumnado para favorecer la participación del profesorado en el logro de la mejora de la cohesión grupal. Se analizan las dificultades y oportunidades así como los factores de vulnerabilidad relacional para posibilitar las condiciones para que todo el alum- 
nado pueda sentir que pertenece al grupo y a la institución escolar. Se ofrece, así mismo, la valoración del profesorado en relación a la metodología seguida y las oportunidades para la mejora de su práctica educativa en el marco del grupo aula y la prevención de la violencia escolar a través del aprendizaje de la convivencia implícito en los procesos que se proponen estrechamente relacionados a la vida cotidiana de la institución escolar más que a un programa concreto.

Palabras clave: prevención violencia, participación profesorado, grupo, sociograma, vulnerabilidad relacional, pertenencia grupal.

\section{INTRODUCTION}

The process of socialisation and intervention in relational dynamics must be considered a main objective of social action as it is a context in which learning takes place for a significantly long period of the students' lives and where relational skills and competences are learned and put into practice.

All of the phenomena that arise in society also arise in correlated fashion in education centres, which are considered microsystems of the social system. This idea does not have a mechanistic base, which would make it difficult to instigate change in the school environment, but is more of a holistic approach, in which there is a conception of an "everything" that transforms and is transformed through the parts that it consists of.

It could therefore be stated that what happens at school is happening in society and that the events that take place in the social environment are simultaneously taking place in education centres. These are not separate identities, but rather form part of the same reality in which relationships are established with common rules based on the inherent characteristics of the context.

Although there is fairly generalised agreement regarding the importance of said process in the modern world, the analysis is made from different perspectives, which involve new ways of interpreting the role of the educational institution, of the pupils, and of the teachers themselves in a society like that of today, in which there are so many major changes afoot in its structures and interpretations of reality.

This debate has come to examine and debate the role of the school, of the family and the socialisation model, along with their opportunities and risks (Van Haecht 2006), coming to question different models of adult intervention throughout the education process. Socialisation can be seen as a product to be consumed on the basis of the comprehension of certain rules of the social game that are established as a set of more or less organised interactions or, otherwise, can be seen as an ongoing and dialectic process involving all members of the education community and in each of its contexts in order to benefit democratic participation.

The same rituals and conducts do not always have the same meaning, but depend on the community, context, space or moment. Similarly, words or gestures change meaning depending on who produces them, where and how, all of which 
introduces major complexity and, in some cases, comprehension difficulties for adults or children, and which can lead to disconcert. From here stems the need to establish the axes that should guide this socialisation process.

Unfamiliarity among people generates incomprehension, invisibility or distrust and also makes communication more distant and more difficult. Recognition of each person and their individual characteristics can help respond to their individuality by showing respect and can create spaces in which each person has their place and is able to respond to the demands of the environment, the peer group and teachers.

The priority would therefore be for the educational institution to be able to create an atmosphere in which mutual understanding is possible as a precept for being able to respect each other. The ways in which people are received in everyday situations, are catered for in times of change, and the adult view in different personal situations favour visibility, the creation of a space that recognises and empowers mutual understanding and opens the doors to relationships between people, while avoiding interpretations arising from ignorance, prejudices or contempt with the consequent vulnerabilisation, as manifested by studies of schools at a time when they are for some people lawless spaces where a lack of respect is shown by adults and between peers (Merle 2005).

\section{THE GROUP CONTEXT OF LEARNING TO COEXIST}

Education centres are organised into groups that share educational spaces and objectives for several years. The group is formed by increasingly more heterogeneous individualities both in terms of their own biographies, and of the diversity of modern society and the appraisal of the universal right to education until 16 or 18 years of age. For all these reasons, it has gained major importance as the context for a form of learning in which attitudes, values and the individual and collective identity are constructed (Dalloz 2003).

Pupils, and especially secondary pupils, are not "naturally" disposed to accept all of the rules of social and school life, less so at a time when education centres are places where different forms of socialisation coexist (leisure, youth cultures, consumer society, etc.) and because it is in the group that all of the identities and forms of relation imposed at school are put into practice.

Hence the need to characterise the group in order to create a context that can make it possible to understand how and why links, affections, rejections or relationships are established between individuals and also to be able to intervene educationally. The group as a social reality follows a process of social categorisation from the moment its members know that they belong to it and people outside of it confirm it (Toczek 2004) and they possess a series of characteristics for defining the same. Therefore, the people that a group consists of have common:

- Group awareness knowing each element it is made up of

- Sense of participation in common objectives as an end to their actions 
- Reciprocal dependence. They can and should help each other to achieve the targets they have set

- Reciprocal action as they must communicate with each other

- Unitary action as they can behave as a unit at certain times

- Internal structure as each member has a specific role

These different characteristics of the group make it possible to notice and explain some of the causes for the relationships that arise within the group, the way in which each person senses their belonging, how relations are established between the subgroups that are organised within the group and the different intensities of said relations or animosities.

It is not a case of reaching a single group thinking, but of respecting the idiosyncrasy of each of its members, promoting personal value and offering an opportunity to display individual skills, and to make work and communication possible in learning situations and other activities.

The experiences that pupils have of these group relationships will influence their individual and social development, both positively and negatively by creating each person's image. Therefore, there is a need to seek the creation of people's own space, where they can associate and establish relationships that empower cohesion, that being the process in which the actions of teachers are so important in terms of the style of their differentiated relations, roles and responsibilities, rather than through cognitive processes (Dubet 2002), which demands clear control by the adult person of his or her skills and socialising actions in order to guarantee the efficacy of their professional actions.

\section{RELATIONAL NETWORKS AND SENSE OF GROUP BELONGING}

In the first stage of the formation of a group, its members may be unmotivated or fearful of communicating with each other. They are typically unwilling to express their opinions, attitudes or beliefs until a minimum level of mutual trust is attained.

The moment the members appreciate the fact that they belong to a group, complicities, affections and sentiments of inclusion are created that favour the deliberation and establishment of rules for coexistence and organisation in order to achieve group rather than individual targets and thus not only achieve comprehension and the need for such rules but also to fundamentally appropriate from the same the bases for learning about democracy and respect (Raveaud 2006). Identity and a sense of belonging can be achieved through external aspects, such as signs of identity, group rituals or the centre itself, depending on the idiosyncrasy of the school or even the country (Raveaud 2006) or through participation in and management of the group.

The objective being pursued, in all cases, is a sense of belonging as a key factor of cohesion, as its absence constitutes a risk factor, as it generates feelings of animosity towards its components, towards those who lead it and towards the 
proposed objectives that could have repercussions in the form of negative behaviour, opposition, violence, passivity, isolation or absenteeism with a personal and group cost.

\section{Relational vulnerability}

We use the term "vulnerability" to analyse the relational situation of people in the group while considering whether they are invisible, unelected, rejected by a relevant percentage of the group or negative expanses whatever the cause (personal or cultural characteristics, school performance, fear of the reactions of others or a combination of factors) in such a way that the groups' relations and welfare are at risk and a context is generated in which there is a likelihood of behaviours or situations being generated that can have a negative effect on the person or group.

This situations considered to be vulnerable determine the positive perception (acceptance of the group) or negative perception (rejection of the group). In turn, these vulnerability factors are the bases for situations of conflict, violence, absenteeism and, undoubtedly, poorer academic performance.

\section{STUDY OBJECTIVES}

The study objectives are focused on the study of groups in order to:

1. Make an in-depth relational analysis from a quantitative perspective.

2. Compare and contrast the data and analysis with the teachers' perceptions of the people in the group (as we also possess nominal information).

3. Defocalise the interpretations offered by the teachers of the individual relational difficulties in order to move on to the group analysis.

4. Propose to the teaching staff ways of acting that might affect relationships in the whole group in such a way that it can be a positive place for everybody.

\section{STUDY POPULATION AND METHODOLOGY}

The data being offered was obtained through the sociometric exploitation of 480 groups of male and female pupils at 65 state and publicly funded private primary and secondary schools in Catalonia. The study involved the participation of 4275 female and 4414 male pupils, of which 4261 were studying primary and 4462 were studying secondary education.

The research model corresponds to Participant action research with the teachers and professional agents in the education centre. This was considered the adequate model as it is the actual teachers that were the agents of research and the key protagonists in participating in this analysis, which was not only designed to understand the facts but also to propose changes to the framework of the educational institution. 
The sociogram was used as the base instrument to enable the study of the evolution of groups and the positions taken by individuals within them, disregarding the problem of the internal structure of each individual Moreno (1925). It is therefore an instrument for exploration and diagnosis, designed to find out the extent (the word sociometry stems from the Latin terms socius-to be social and metrum: measurement) of social relationships between the members of a group, revealing the existent preferences and rejections and the self-perception that each person has of their situation on the basis of the rejections and preferences of others.

The sociometric test technique, developed later by others such as Northway (1967) makes it possible to measure the degree to which the subjects are integrated, excluded or invisible in the structure of the group, and the existing personal relationships between individuals. It expresses their affinities and rejections by means of a series of indexes and graphic charts.

In our case, the centres taking part were offered access to an Internet site that was specifically constructed for the group GRODE http://portal.grode.org and that includes an Online Sociogram where the pupils answer 4 questions. The scope exists for an unlimited number of responses in which different options are ordered by preference. The questions are:

- What people in the group do you want to be with in an activity (game or work)

- What people do you not want to be with for an activity

- Who do you think has chosen you

- Who do you think has rejected you

The program processes the responses and by means of a mathematical and statistical treatment offers qualitative information (the names chosen by each person for each question) and quantitative information (indexes and percentages based on their responses) and interactive relational maps that help provide a view of the answers given by the pupils.

This information enables the teacher to make their own analysis and compare their perception with what is offered by the questionnaire.

1. Find out the level of acceptance of each person within the group.

2. Evaluate the degree of cohesion among the people in the group.

3. Locate the most rejected people and the most highly valued ones (the most popular people in the positive and negative sense).

4. Locate isolated people, those that neither inspire interest nor rejection.

5. Verify the stability or dynamics of said relations.

6. Find out about the positive or negative expansiveness of people.

7. Evaluate positive self-evaluation (expected elections and actual ones) and negative self-evaluation (expected rejections and actual ones).

8. Find out about the groups' perception in relation to individual behaviours (how many people expect to be accepted or rejected by each member of the group). 
By comparing and contrasting the two perceptions (that of teachers and that of pupils), risk and vulnerability factors can be identified in relation to the socialisation process and the possible causes and, more especially, changes can be managed that form the starting point for determining group actions that can minimise this relational fragility and improve communication between pupils.

\section{PUPILS'RESULTS}

A preliminary analysis is offered of the factors that suggest relational vulnerability and that have been most highly valued by teachers. These factors are:

- Elections received

- Rejections received

- Positive self-evaluation (elections supposed and elections received)

- Negative self-evaluation (rejections supposed and rejections received)

\section{ELECTIONS}

The elections that a person receives from the members of the group in which they spend a large amount of their school life is a key factor for determining their welfare, their motivation to perform activities (study, leisure), shared interests, affections, points of view and constructions of their identity (self-image, selfesteem and self-concept). There is no need to have a very high number of elections, but rather it is important for those elections to be significant (and therefore perceived) and stable.

The first relevant data is that of people that have no elections or only have one, which is an extremely fragile situation and is considered by teachers to be a cause of conflictive situations (violence, absenteeism, marginalisation).

Of the pupils studied (12.316 people), 1230 people, $9.99 \%$ of the sample (9.0\% girls and $10.9 \%$ boys) have no links with their group: Figure 1, which determines the relationships they might establish. This circumstance is easily noticed by the protagonists and the rest of the group. There is also an unfavourable situation for 3975 people, $32.3 \%$, who receive between 2 and 5 elections, which is a fairly low number when we consider that there was no limit on the number of responses. Therefore, $42.29 \%$ of the pupils have very few links to the group they belong to.

\section{REJECTIONS}

In every group relational difficulties or less affection occur among people, which determine rejection when it comes to performing joint spontaneous activities. From the not necessarily numeric balance between elections and rejections, the relational climate can be derived and the possibilities for coexisting positively. 
This information is therefore of major importance given that it reflects unrest and negative responses from the people providing it. In this case, 1634 people, $13,3 \%$, out of the total $(10,1 \%$ girls and $16,1 \%$ boys $)$ have more than eleven rejections, Figure 2, which represents between 30 and $40 \%$ of the group. This situation is especially serious for 189 people, who receive more than twenty-one rejections, a number which represents almost the entire group.

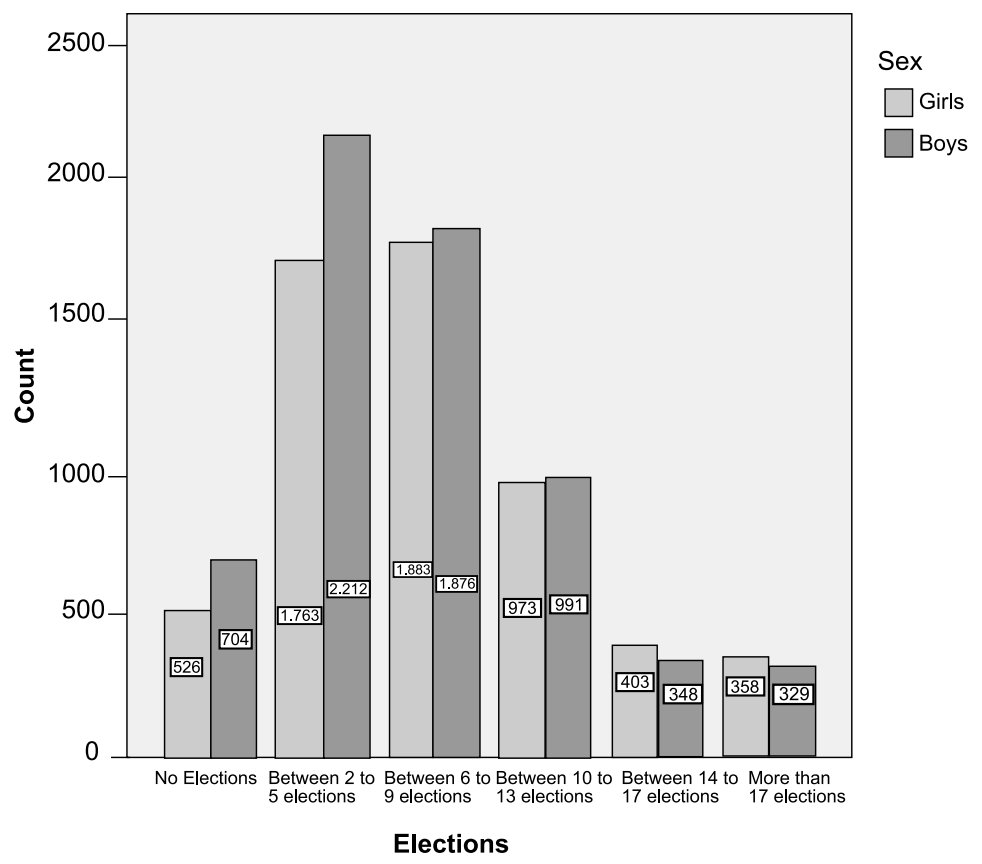

Figure 1. Graph of elections received. 


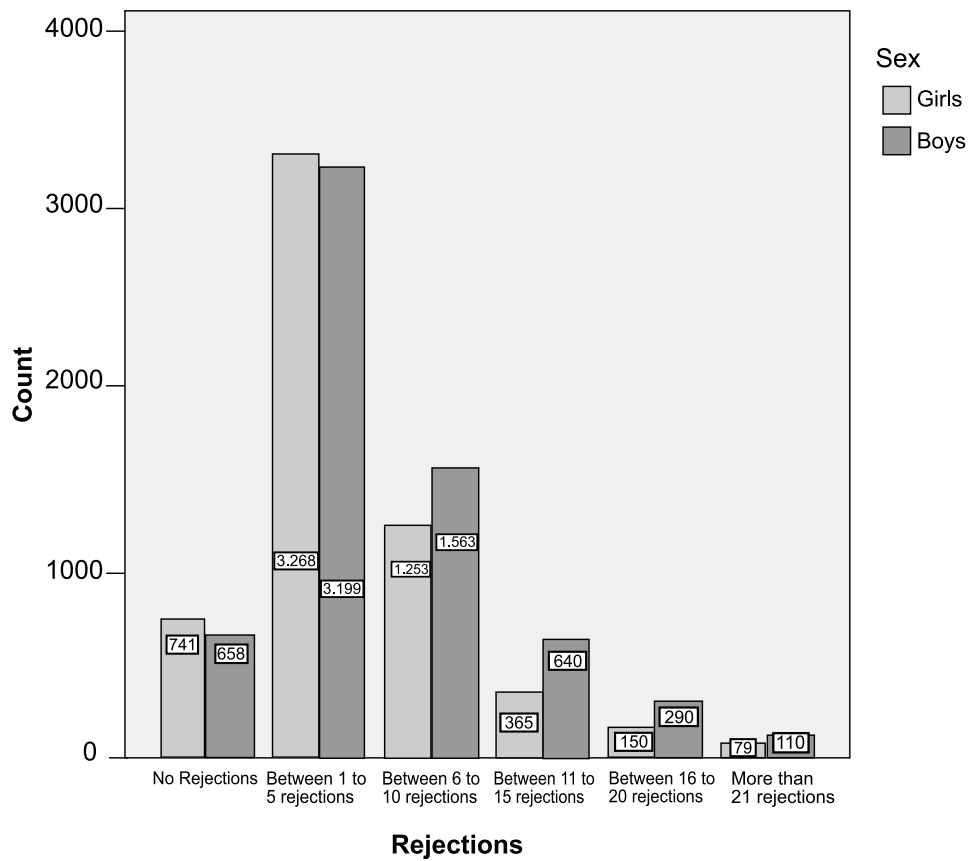

Figure 2. Graphs of rejections.

\section{UNADJUSTED SELF-EVALUATION}

The perception one has of their situation in the group is a determinant factor of the attitudes and responses that could occur in different spontaneous relational situations, or those that are programmed by teachers. The adjusted selfevaluation shows that the person clearly interprets the group's responses. The self-evaluation is positive (elections received and expected) or negative (rejections received and expected).

The analysis of the study population shows that $55.9 \%$ of boys and $54.8 \%$ of girls have a low positive self-evaluation (Figure 3 ).

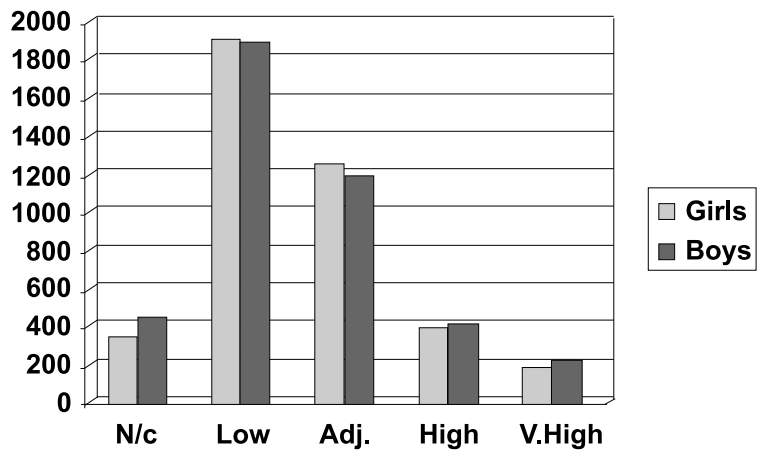

Figure 3. Positive self-perception. 


\section{INDEX OF POSITIVE SELF-EVALUATION}

Table 1. Interpretation of the Values of Positive Self-perception

\begin{tabular}{|c|c|}
\hline Code & Meaning of the Indexes of positive Self-evaluation \\
\hline $\begin{array}{l}\text { N/C. } \\
8.6 \% \text { Girls } \\
10.9 \text { Boys }\end{array}$ & $\begin{array}{l}\text { People that did not answer the question: "Who do you think has chosen you?" or that } \\
\text { answered it but did not make any choices. }\end{array}$ \\
\hline $\begin{array}{l}\text { Low } \\
46.2 \% \text { Girls } \\
45 \% \text { Boys }\end{array}$ & $\begin{array}{l}\text { People that did not think they would get many elections. In fact they get more than they } \\
\text { expected. }\end{array}$ \\
\hline $\begin{array}{l}\text { A d j u s t e d } \\
30.7 \% \text { Girls } \\
28.6 \% \text { Boys }\end{array}$ & $\begin{array}{l}\text { People that expected to get a certain number of elections and the reality more or less coincides } \\
\text { with their expectations. }\end{array}$ \\
\hline $\begin{array}{l}\text { High } \\
9.6 \% \text { Girls } \\
10 \% \text { Boys }\end{array}$ & People that thought they would get more elections. In fact they get fewer than they expected. \\
\hline $\begin{array}{l}\text { Very High } \\
4.9 \text { Girls } \\
5.4 \% \text { Boys }\end{array}$ & $\begin{array}{l}\text { People that thought they would get a lot of elections. In fact they get far fewer than they } \\
\text { expected. These are frequently rejected people that try to compensate for this rejection through } \\
\text { positive expansiveness. }\end{array}$ \\
\hline General comments & $\begin{array}{l}\text { Positive relations are not well perceived such that the distance between possible affinities } \\
\text { and their perception makes it difficult to create positive relational links. }\end{array}$ \\
\hline
\end{tabular}

As for negative self-perception (rejections) $40.2 \%$ of girls and $32.6 \%$ of boys have a high negative self-perception, i.e. they think they will be more rejected than they actually are (Figure 4).

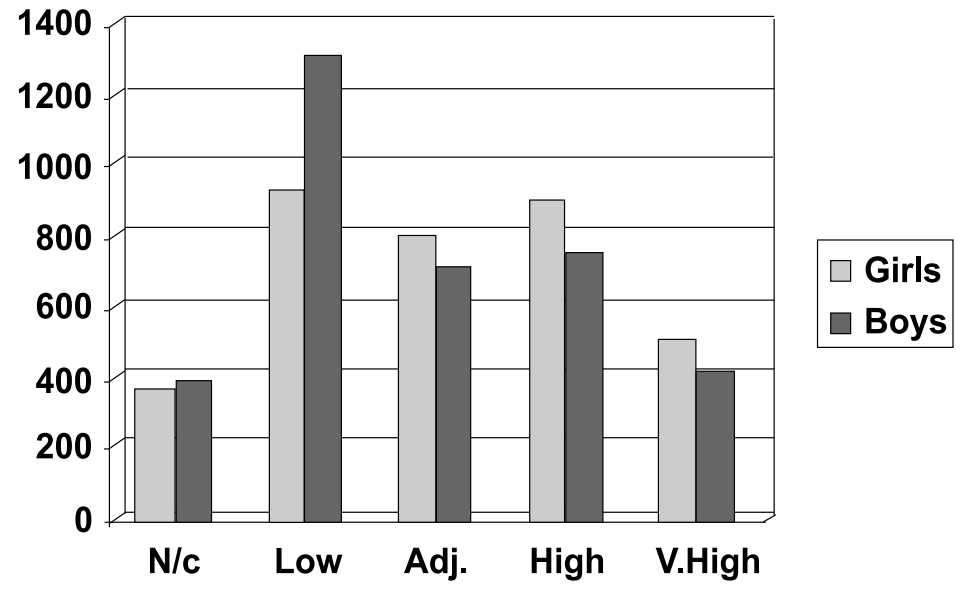

Figure 4. Negative self-perception. 


\section{INDEX OF NEGATIVE SELF-EVALUATION}

Table 2. Interpretation of the Values of Negative Self-perception

\begin{tabular}{|c|c|}
\hline Code & Meaning \\
\hline $\begin{array}{l}\mathbf{N} / \mathbf{C} \\
10.5 \% \text { Girls } \\
11.1 \% \text { Boys }\end{array}$ & People that did not answer the question: "Who do you think rejected you?" \\
\hline $\begin{array}{l}\text { Low } \\
26.4 \% \text { Girls } \\
36.5 \% \text { Boys }\end{array}$ & People that thought they would get few rejections. In fact they get more than they expected \\
\hline $\begin{array}{l}\text { A d j u s te d } \\
22.9 \% \text { Girls } \\
19.9 \% \text { Boys }\end{array}$ & $\begin{array}{l}\text { People that expressed a certain number of rejections and this more or less coincides with their } \\
\text { expectations }\end{array}$ \\
\hline $\begin{array}{l}\text { High } \\
25.7 \% \text { Girls } \\
21 . \% \text { Boys }\end{array}$ & People that thought they would get more rejections. In fact they get fewer than they expected. \\
\hline $\begin{array}{l}\text { Very high } \\
14.5 \% \text { Girls } \\
11.6 \% \text { Boys }\end{array}$ & People that thought they would get a lot of rejections. In fact they get far fewer than they expected \\
\hline General comments & $\begin{array}{l}\text { Negative relations are not very well perceived but are feared because } 40.2 \% \text { of girls and } \\
32.6 \% \text { of boys sense rejections that do not exist. This perception of possible relational } \\
\text { difficulties and the reality makes it hard to create positive relational links and could generate } \\
\text { reactive attitudes }\end{array}$ \\
\hline
\end{tabular}

\section{RESULTS OF THE DEBATE WITH TEACHERS}

To complete the discussion an evaluation is offered as made by the teachers at the 65 education centres, 594 people with different training and levels of professional experience, who are responsible for tutorial activity with the groups or that teach different areas of curricular content. The data responds to three aspects:

1. Achievement of the proposed objectives

2. Evaluation of the participative methodology

3. Change of classroom methodology

Their evaluation first focused on the achievement of the 2 agreed objectives (Figure 5).

- Find out about the pupils' relational dynamics

- Detect factors of relational vulnerability

- Act to improve group cohesion

- Increase teachers' skills to improve the process of socialising pupils 


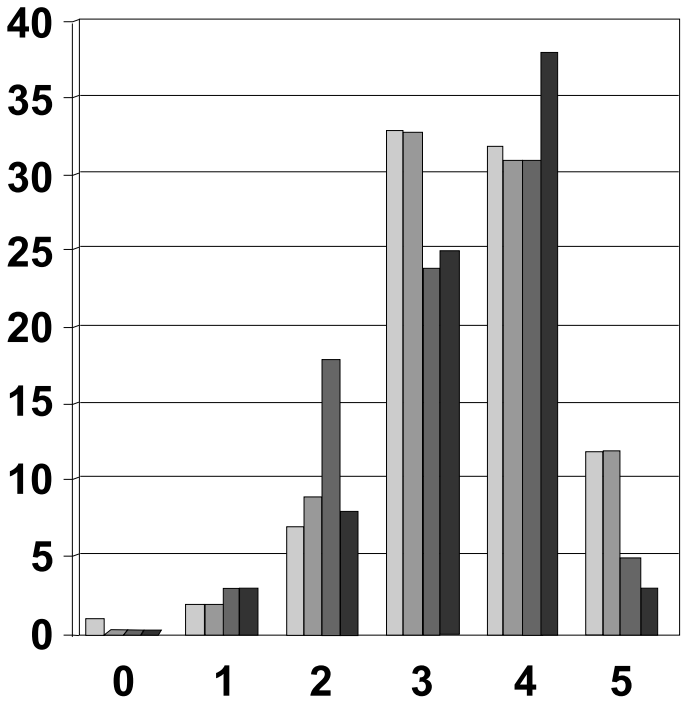

1. Find out abour the pupils'
relational dynamics
$\square$ 2. Detect factors of relational
vulnerability
$\square$ 3. Act to improve group cohesion
$\square$. Increase teachers' skills to
improve the process of socialising
pupils

Figure 5. Teachers' evaluation of the achievement of the formulated objectives.

Assuming a change of methodology and becoming mere spectators of the pupils' behaviour or reproducers of external orientations by forming part of the research team and participating in the analysis and interpretation of the data represented a change of viewpoint (Goudeaux, A et al 2008) and attitude when faced by the challenge of understanding relational dynamics and improving them (Figure 6).

Finally, the fact that the debate was focalised on the framework of the educational practices of teaching staff as a factor to promote socialisation and prevent violence was clearly valued (Figure 7).

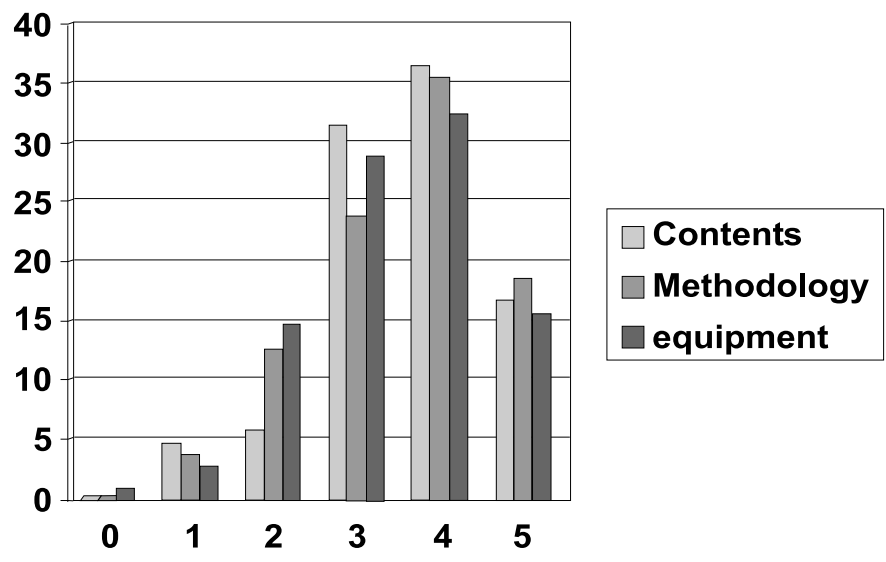

Figure 6. Teachers' evaluation of the methodology used and the contents jointly decided by them. 


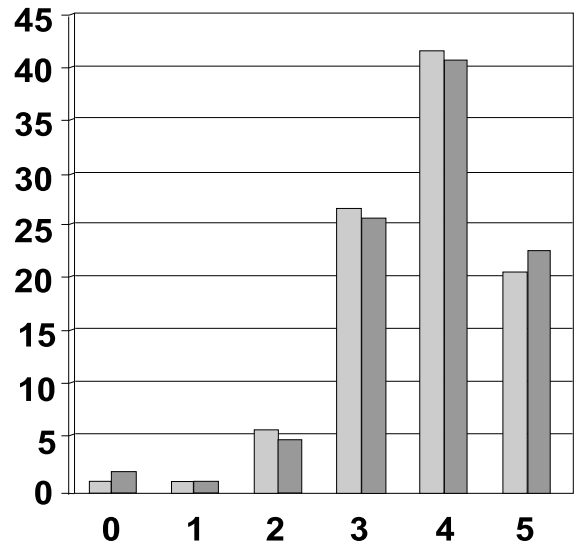

Change the framework

Improve practice

Figure 7. Improvement of methodology.

\section{DISCUSSION}

This initial analysis of the group data and the debate with teachers at the participating centres reveals the need to interpret and reinterpret the dynamics and their causes without prejudice in order to find educational methods to intervene in improving in pupils' relationships.

One of the first responses by teachers to the information they obtained from the pupils via the sociometric questionnaire shows that there is a tendency to give an explanation for the acceptance of pupils' relational forms or the factors that make them difficult: Body image, school performance, cultural differences, lack of initiative, parents' jobs ...: “it's always happened, "it happens in society”, “it's the crisis of values"....

By analysing in more depth and considering the people individually, another type of interpretation frequently occurs "rejection by the group is a logical reaction to an individual behaviour": he earned it, they aren 't motivated, she's got no resources, there's something about him, they don't want to take part ..., which individualises the problem, and as shown in the aforementioned studies, perpetuates the individual problem. "When he changes, the group's responses will change."

These focuses put in doubt any motivation to look at the debate in greater depth and perform group education actions rather than individual actions (who rejects and who gets rejected) that do not improve relations and perpetuate the perception pupils have of themselves and others.

The discussion should include an analysis of the points of view of the protagonists and promote the consideration that coexistence and the prevention of violence cannot be assumed using punitive models, but rather educational models, and with the implication of teams as a key factor in the process.

In all groups, and therefore in class groups, there is an individual sociometric status that is each person's position in the group, and this affects the set of percei- 
ved behaviours considered normal by the possessor of a status, which leads to individual and group attitudes, behaviours and motivations and, in turn, these are reinforced by the tacit or explicit responses of the rest of the group and the teachers.

One of the questions being proposed for the debate is, therefore, how teachers assume the role they play in this process, given their status, as depending on how they act, they reinforce, and their vision ends up being predictive of success or failure at school and of the way people adapt (Lazega, et al 2008).

The representation that teachers have of the norms has an effect on the structure of the group and the education centre with repercussions on the dynamic that is present throughout the pupils' education process, perpetuating roles or otherwise offering opportunities to promote possibilities for improving the social cohesion of the group (Hirtt 2004).

Another key factor in the analysis is the valuation of the communication networks that are established within the group, identifying the emergence of leaderships, the causes for their creation and maintenance, and adjustment with respect to the real position and that perceived by each member within the group, as this behaviour is derived more from perceptions than from the facts. It is hard to change attitudes if there is no change of perception. The value of this detection is essential for intervening in exclusive situations as the person or collective ends up assuming the group or institution's problems as being their own, a process of internalisation (Vygostki 2000) that leads to injustice and violence (Quiroz, 2006).

Finally, another point for debate can be formulated on the basis of the consideration of the search for new forms of comprehending and interpreting each person or group in order to find participative ways of implicating management teams and teaching teams (Lessard et alt 2009) in such a way that they can overcome the model of partial and occasional projects in order to change or modify the causes that perpetuate difficulties and biases (Defrance 2003).

This debate must therefore seek to promote a line of education that integrates actions in a centre's education project, in order to change punitive (reports, files), exclusive (expulsions), or marginalising (most cases of repeating the year) actions that provide no response to complex situations and do not give the pupils a voice by means of dynamic and changing forms of relation, replacing them with other actions that enable the participation of the whole education community.

In this sense, professional implication is increased in order to find responses that can improve the relational dynamic between pupils, with adults and within the framework of the institution, thus improving both welfare and the learning process itself (Charlot 1992); along with the need to alleviate and avoid conflictive situations that only make coexistence more difficult.

\section{REFERENCES}

Charlot,B (1992) École et savoirs dans les banlieu...et ailleurs. Paris. A. Colin Comellas M. J. \& Lojo, Mirta (2008) Un canvi de mirada a la violència a les escoles. Octaedro. Barcelona. 
Dalloz Danielle. (2003).Où commence la violence. Paris: Albin Michel.

Defrance, B. (2003). Sanctions et discipline à l'école. Paris: La découverte.

Dubet, F. (2002). Le déclin de l'institution. Paris. Editions du Seuil

Goudeaux, A Stroumza, K; Durand,M; (2008) Faire advenir des solidarités, compétences et identités dans les relations de travail: analyse des dimensions formatives de l'activité des accessoiristes de théâtre. Education et sociétés. Dossier : Relations et éducation n22.pp 13-27

Hirtt, N (2004) L'école de l'inégalité.Bruxelles. Éditions Labor

Lessard, C.; Canisius, P.; Larochelle, M.(2009) Quelques facteurs facilitant l'intensification de la collaboration au travail parmi les enseignants : le cas des enseignants canadiens Education et sociétés. Dossier. Des enseignants pour demain. $\mathrm{N}^{\circ} 23 / 1.59-77$

Lazega,E.; Mounier,L.; Snijders,T.; Tubazo,P.; (2008/3) Réseaux et controverses: de l'effet des normes sur la dynamique des structures. Revue française de sociologie. Vol. 49. 467.498

Merle Pierre. (2005). L'élève humilié. L'école, un espace de non-droit. Paris: Puf.

Northway, M.L. / Weld, L. (1967). Test sociométrico. Buenos Aires. Paidós.

Quiroz,J.M. (2006) L'école et ses sociologies. Paris. Armand Collin

Raveaud Maroussia. (2006). De l'enfant au citoyen. Paris: Puf.

Toczek Marie- Christine, \& Martinot, D. (2004). Le défi éducatif. Paris: Armand Colin

Van Haecht,A. (2006) L'ècole à l'epreuve de la sociologie. De Boeck. Bruxelles Vygotski, L. (2000) Pensamiento y lenguaje. Barcelona. Paidos 